\title{
Residing Tradition of Muslim Community in Java Northern Coastal
}

\author{
Atiek Suprapti, Dhanoe Iswanto \\ Department of Architecture, Engineering Faculty, Diponegoro University, Semarang, Indonesia \\ Corresponding e-mail: atiekbudiarto@gmail.com
}

Article info:

Received : 26-06-2018; Revised : 24-09-2018; Accepted: 24-09-2018

\begin{abstract}
The development of globalization has been encouraged social changing of the city. The less social behaviour occured in the daily of urban community and has became a preferred life style. This situation will be a seriouse threat for the urban social life. A good city should be able to create many places for its people, that could make people feel comford and feel like home to live inside. A place expresses its local culture has potential to be a local identity. Locatity is an imporant point that is needed by a nation to attrach roles in globalization era. The characteristic of muslim city is a place to muslim community live in that do the Idlamic shariah well. Since in the 11 'th century the region of north coast of Java has been known as an entrance gate of Islam teaching in Indonesia. The region of Demak and Kudus are the old city which are saving many artefact and tradition of living of muslim community. Kauman is an important place related to this case. The purpose of this paper is to describe the phenomena of Muslim residence present in Demak and Kudus, using descriptive qualitative methods. The result is that the existence of Muslim residence in this region occured because of the strong support of coastal economic. There is a considerable difference between the Muslim residence in Demak and in Kudus. The Muslim residence in Demak develops with the character of hierarchical, dependent society; while in Kudus develops an egalitarian and independent character of residence. In Kudus known the social kinship of 'Gusjigang', while in Demak emerged the Kasepuhan \& Notobratan kinship which was the heir of Sunan Kalijaga. The characteristic of the two Muslim cities on the north coast of Java shows the uniqueness of Muslim cities that are not found in other areas.
\end{abstract}

Keywords: Social cohesion, city heritage, Muslim community

\section{Introduction}

The term residing means to live and to settle in certain place with all activities as a social being. Residence' is a combination of elements of environment physical with human perform social activities and produce physical and non physical products (Snyder dan Catanese, 1979). According to Rapoport (1977), the social aspect of human culture (trust, family relations, social organization, social interaction between individuals) is a decisive part of physical formations in a built environment, includes a factor of change whose is influenced by outside factors. The next views are from Pangarsa (2009) and Mangunwijaya in Budihardjo (2006), they explained that the residence is not only related to the physical container aspects and human cultures, but also the transcendental aspects.

The characteristics of Muslim society (Sensa 1981, Ekomadyo 1999) are: (1) societies that use the guidelines of Shari'a of the Qur'an and Hadith, (2) doing the amar ma'ruf and nahi mungkar (doing good thing and preventing bad thing), and (3) the unity of the Muslim community based on the values of its faith. In some Muslim cities in the world found the morphologic characteristics that among others, are the pattern of buildings and irregular 
roads, the cul de sac pattern that serves as a semi private space (Ekomadyo, 1999). The muslim cities develope as pattern of spontaneously - unplanned. The Muslim city also adheres to the concept of providing protection especially to women and children. The city pattern as mentioned above is known as 'organic' pattern (Lynch, 1981, Kostof, 1991) and Peponis (1987) labeled it with 'grid deformation'. Furthermore Peponis (1987) conveyed a seemingly irregular pattern in this Muslim city meaning the expression of the moral message of the culture of society. Meanwhile Sensa (1986) explained the idea of 'Islamic Settlement'. Starting from the concept of 'Darussalam' (QS: 6: 126-127). These concepts include:

1. Muslim relationship with Allah SWT, this activity requires physical spaces like mosque, open field and majlis taklim.

2. Muslim relations with each other, this need is manifested in residential houses, hospitals, schools, markets, government offices.

3. Muslim relation to the content of nature, the place to life and die. The physical needs of space are manifested in open space, outdoors, farmland, spaces for communication, and graves.

Thus the Muslim city is a reflection of the relationship between man and God, the relationship between humans each others, and the relationship between humans and the surrounding natural environment. This concept to be known as Habluminallah, and Habluminannas. The aims of study is to describe the phenomenon of muslim residence includes of physical feature, and socio-cultural aspects. Using methods of survey literature study of references, previous study, and journals related to the topics. DescriptiveQualitative methode is used to explain the result of research.

\section{Discussion}

\subsection{The Characteristic of Cities in Java North Coast}

The earliest civilizations of Indonesian cities grew and flourished in the hinterland, around coastal rivers, and in river estuaries (Wartheim 1999, Tjandrasasmita 2000). Santoso (2008) describes the city of Java is the development of urban and building structures based on Javanese cosmology. Technically the city of Java is divided over the city that is sacred in the south and the profane city in the north. According to Santoso (2008) cosmology also regulates the nature of the relationship between humans and things. Various government or religious activities require parades, performances, arts and so on. The ceremonies are a medium to actualize the unity of public life in accordance with macrocosm law (Tohir 1997). The structure of the Java Coastal city - adopted from Demak - largely comprises the intersection of two axes of the East-West axis and the North-South axis, centred on the open space of Alun-alun (Wiryotomo 1995). In the vicinity there are important buildings such as Keraton, Mosque, Market, and ethnic village that are grouped separately. The square is the node point, the meeting place between the government of the palace, the people (the subjects), as well as the religious spiritual. In the square a variety of ceremonies or crowds invite the people to do, which is intended to promote the existence of government. In the cosmological view, the alun-alun is a meeting between celestial and terrestrial energies. Worldly energy is reflected by the settlement and market arrangement. While the celestial axis connects between man and his God, symbolized by the mosque. The palace of Sultan throne place is a symbol of the leader as 'representative of God', which is a regulator of the world. Outside the palace located villages which are mostly people's reside inside. There is 
a real Muslim-Javanese social life, which are studying religions, establishing prayers, praying / sholat, doing the Javanese spiritual life such as ceremonies for birth, death, marriage, and so forth. Thus the balance within the settlement environment is a reflection of harmony between macrocosm and microcosm built on the spiritual Islam-Java.

The development of the city of Demak is closely related to the efforts of Walisanga figures, who are religious scholars - political experts - trade experts (Qurtubi 2003). Walisanga in Indonesia are known as nine (9) saints who dedicated their life to spread Islam in Java in 14th century to 15th century (Suprapti, 2018) There are at least four member of Walisanga were living in Demak and its surroundings, namely Sunan Bonang, Sunan Kalijaga, Sunan Muria and Sunan Kudus. This situation allowed that the policies was made by Sultan to be based on Islamic teachings. The city's great mosque was established in the centre of the city along with Alun-alun, Keraton and market, while the people's settlements spread to form ethnic groups. The palace of Demak's Kingdom was not built in a more permanent structure such as a mosque, and along brick wall around the palace flattened to the ground for residential housing after power shifted to Pajang's Kingdom to. The settlements spread along the Tuntang river. River meaning economic, religious, and defense of security. Northsouth oriented house building means community applyed a cosmological views in their built environment (Rapoport, 2001). Meanwhile from their residence found a langgar / mushola established in a group of houses, which was support by community participation, by the results of people endowments. One of famous tradition held by the city's great mosqueuntil nowsaday is rituals of Grebeg the heirloom carnival in month of Dzulhijah. It is a symbol of a sacralization of the heirloom. The mosque that was founded since the 15th century is well maintained, the tomb of Sunan Kalijaga Kadilangu become a religious tourism destination. In the vicinity of Demak's great mosque locates a village where the santri and religious leaders live for generations called Kauman. Observing from the historical record before the founding of the mosque, there were established the first pedepokan or traditional islamic boarding school where Raden Patah conducted spreaded the teachings of Islam (Tetuko, 2000). Probably these santri dwellings developed as Kauman.

Before Islam came, the Kudus area had developed as a zone of transportation line connecting the port of Jepara, the port of Pati in the era of Majapahit Kingdom. Ismail (2000) says there are at least three periods that broadly give a significant influence on the development of the Kudus city. The first is in the Hindu period. At this time developed the Hindu community in the region of Tajuk area. Secondly in the early days of Islam, Kudus had a close relationship with Demak city. Ja'far Sodiq or Sunan Kudus was Kudus city leader was a member of Walisanga who was close to Sultan Demak. Ja'far Sidiq was later appointed to replace his teacher, The Ling Sing (Kyai Telingsing) governing of Kudus. Sunan Kudus established the Al Aqsa Mosque or the Tower Mosque and built the palace. The settlement develops west of Gelis River and has a centre at the intersection between Sunggingan area, Menara roads with Jepara-Pati road (see Figure 1). Around the Al Aqsa Mosque developing Kauman residence, not yet unclear of the time of its establishment, but seeing the grown of Demak and Jepara is possible for Kudus to follow the existing pattern of the making of both cities. At this time Kudus became known as the centre of Islamic education, and the inhabitants of Kudus had livelihoods as traders and farmers. The third period occurred in the 17th -18 th century. Marked by the arrival of Prince Puger (ruler of Demak) to the Kudus city due to defeat in the rebellion against Mataram. Prince Puger with his followers, settled in the east of Gelis River. The place is then called Demakan village. At 
this stage of development the west of the river serves as the centre of government, and east of the river as a 'new' settlement area or later called 'the new Kudus'. At the end of the 18th century, the Dutch moved the original government centre in Kudus Kulon to the east of Gelis River, then built a new city structure with the Alun-alun as its centre, with its northern part there being the Regency, and the mosque to the Westside. The Netherlands also built housing for government employees, Chinese ethnic settlements and Pekojan, flourishing along the main road and around the new city centre. The abandoned old Kudus territory flourished with its religiosity and a strong craft industry. Early 19th century developed clove cigarette industry among indigenous businessmen. The industry that originated from this old Kudus soon developed from the scale of home industry, medium and large industries in the old Kudus and the new Kudus. And cheap labour imported from the north and east. From the 20th to the 21th clove cigarette industry got a shocks, then there emerged a major electronics industry. This industry brings huge profits because of cheap labour. On the other hand the craftsmen in the old Kudus develop new business like a small industries such as convection. The industry was soon favoured by cheap labour and vast market opportunities. Large and small scale industrial activities have spurred the Kudus economy and are able to position themselves as the highest per capita income districts leaving other areas of Central Java.

\subsection{Kauman Village: the Residence of Muslim Community in City Center}

The emerging of Kauman village in the both of ancient cities Demak \& Kudus indicates the existence of similarity patterns of development (typology) culture both tangible and intangible, and its sustainability. The name "Kauman" or "Pakauman", means the dwelling place of religious enforcers or scholars. Kauman residents are called 'kaum' whose located around the city's great mosque (Lombard 2005). Kauman is also defined as a place to live the santri. While santri by Geertz (1989) contains the definition of a group of people which is also called putihan group that are contrasted from abangan groups within the Javanese society. Putihan also defined as a group of Muslim communities who practice religious teachings diligently and they are skilled in trade.

Kauman typologies in Javanese cities show the idea of religion from the Muslim government. In the coastal cities area looks more independent, far from ties with the power of government. While in rural areas such as Yogyakarta and Surakarta, Kauman is normatively bound and functioned with government, or religious leaders (Geertz 1989 , Darban 2000 , Triatmodjo 2010). In Yogjakarta as well as Surakarta most Kauman people are court servant who were paid by the Sultan (Darban 2000). Nevertheless from Kauman Yogyakarta in 1928 was born a group of Muslim reformers group of Muhammadiyah (Triatmodjo 2010).

Some of the arguments (Geertz, Lombard 2005, Darban 2000, Qurtuby 2003, Suprapti, 2012) associated to the formation of Kauman from period of Demak to Mataram are as follows:

Political and defence-security factors, it is necessary to develop Kauman-Masjid concept for syiar Islam and to control public confidence.

1. Religious factor, prosper the mosque is recommended in Islam, at time the mosque serves the centre of education, socio-cultural, even political. 
2. Social factors. The settlers around the mosque or Kauman are the family or relatives of the mosque administrators thus the social life of the mosque's board will be assured.

3. Economic factors. the santri have talents in trading activities so that it can enliven the economic life in downtown area.

4. Spatial factors. With the Kauman village located near the mosque, the layout of the area becomes more effective and efficient. Mobility from residence to worship facilities can be reached on foot and environmentally friendly.
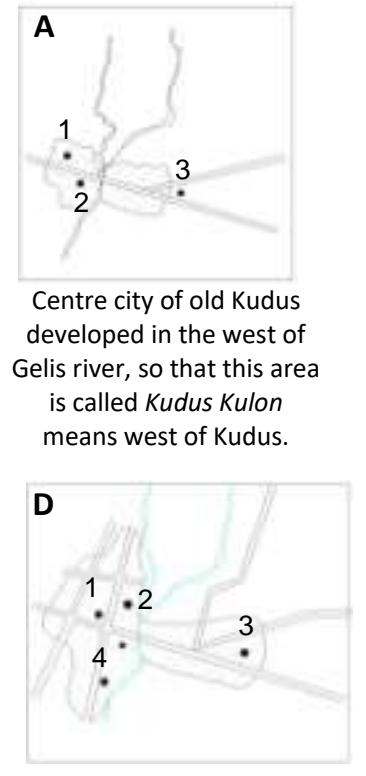

Kudus Wetan developed as faster as Kudus Kulon.

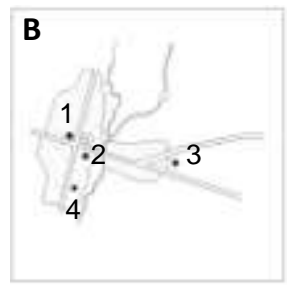

Centre of city developed faster to the east of the Gelis river, so that this area is called as Kudus Wetan

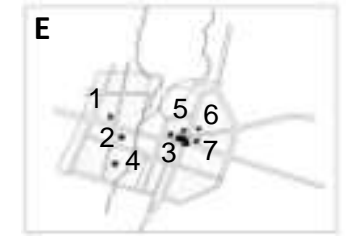

Kudus city develops supported by two character of Kudus Kulon which is a religious traditional, and Kuduw Wetan which is modern one.

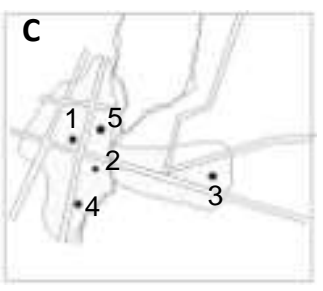

Kudus Wetan developed faster, so that emerged a new centre in location around Alun-alun I pusat baru alun-alun.

\section{EXPLANATION}

1Mosque of Al-Aqsa - Menara

2Mosque of Bubar

3.Mosque of Nganguk Wali

4.Tomb of Kyai Telingsing

5.Mosque of Langgar Dalem

6.Mosque of Madureksan

7.Tomb of Pangeran Puger

Figure 1. Morphology of Kudus city Start from period of before 15 th to the freedom

(Ismail, 2000)

This pattern was strengthened by the time of the Colonial government. The Dutch exploited Kauman formation as politics to control the centre of Java. But at a time when Independence of Republican Government policy which is inclined towards modernization-capitalization slowly undermines the socio-cultural life of the city of Java. The displacement of the palace, the Alun-alun, is an indication of the threat of Javanese idealism. Semarang city and Bandung city are examples of cities that are under such pressure. The interesting reality in Semarang city is the survival of the city mosque with Kauman, so the centre of the city is still humanist. In Bandung city, the city's great mosque is still maintained well, but the Dalem Kahoem (Kauman) is just a name left, because the contents have been turned into a commercial- business area.

Kauman has a distinctive social life character, encompassing the hallmark of a santri village in the city centre; has strong blood ties between its inhabitants; have a homogeneous livelihood; have strong religious ties, very different from other villages. As a small community Kauman with its properties can be strong. Even Lombard (2005) says they are an orthodox society because of their tendency to engage endogamy within their own environment. There are differences in coastal characteristics when compared to those in remote areas. The north coastal shore of Java is cosmopolitan, independent, moving in large and small 
institutions. Heterogeneous citizens, diligent traders and entrepreneurs. The orientation of the settlement is to the city's great mosque. Meanwhile, Kauman in the interior of Java is more conservative, has good relations and is organized with the Palace, engaging in a large institutions, homogeneous population, businessman-trader economy (Dharban 2000, Trihatmodjo 2010).

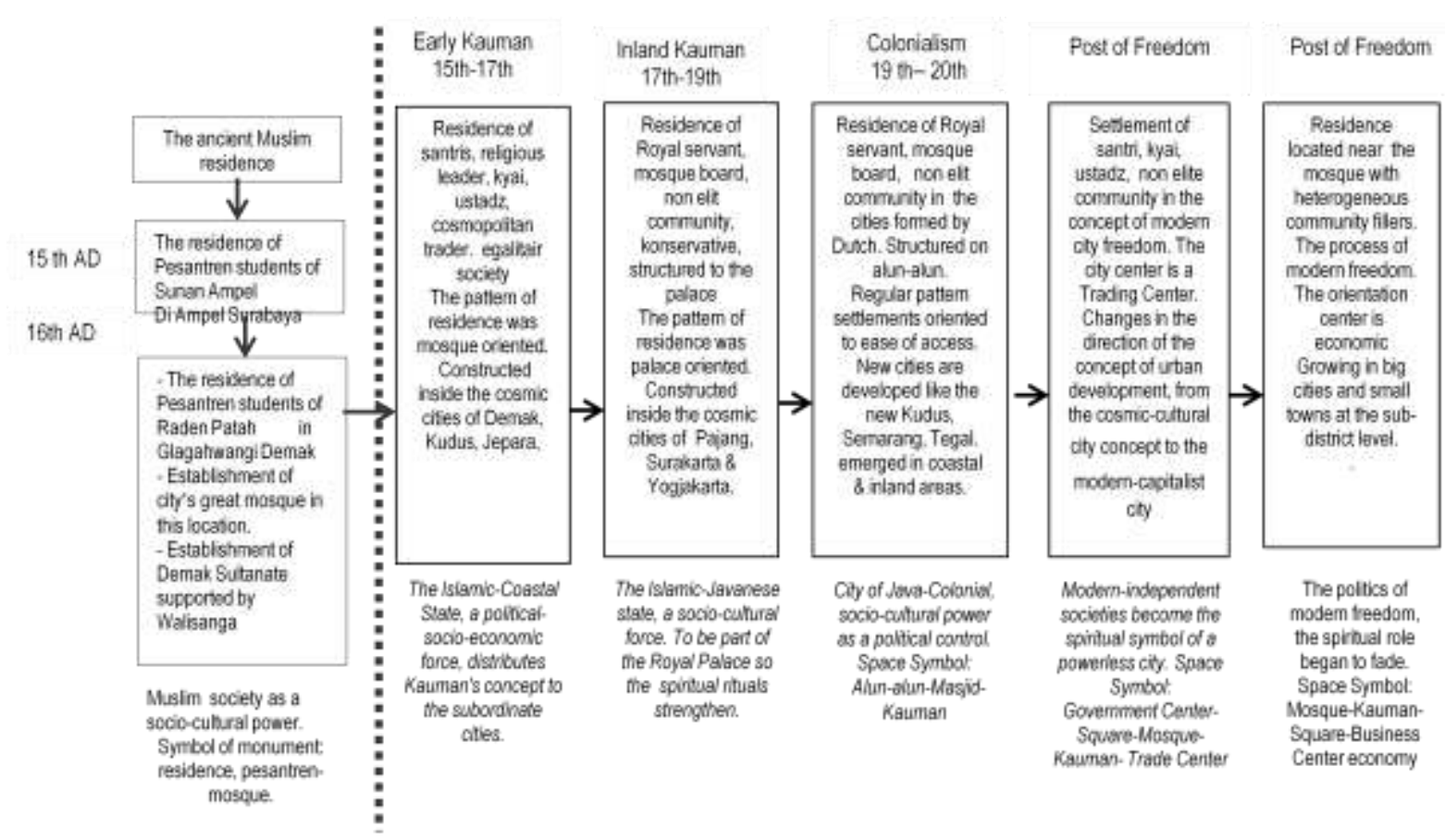

Figure 2. Scheme of era of the making of Kauman and its characteristic

The Kauman people are images of people who are diligent in worship, independent from the influence of political power (Lombard 2005). Most have livelihoods as traders, and many of them are successful traders. From here born the household businesses that later developed into a fairly large industry. Like cigarettes in Kudus, wood carvings in Kudus and Jepara, the publishing industry grew up in Semarang. Being accustomed to administering religious institutions, Kauman people are also good organizers, not a few large religious organizations are hoisted from Kauman, such as Al-Balad in Kudus which is large enough for the scale of the city that engages in religious education. In Semarang the foundation of Sultan Agung Wakaf Agency was born and developed big, take care of pre-school level up to college and manage large hospital. As it described above that the Muhammadiah organization was born in Kauman Yogyakarta and succeeded in developing the network to overseas. In the old Kudus they are the followers of Sunan Kudus who is also a trader, because at that time had experienced the successfull business, so that have emerged a bourgeois lifestyle, which is the exclusive life of the traders. In here lives social-religious activity led by the ustad / Kauman scholars. Some small pesantren or madrassas managed by local Kiai develop in self-reliance. Some are medium and large in size and have a range of services to the regional scale. Pesantren is traditional Islamic boarding school. It has a traditional learning methods such as 'sorogan' (assignment) and 'wejangan' (wisdom) which is using a flexible space (no need the fixed space). Meanwhile the modern pesantren using classroom learning methods. The activities of Islamic study groups or education have attracted Kauman 
and surrounding residents. Kauman seems to be able to become the motor of the economy of the people of the city while the tradition of Kauman religious propaganda has been able to mobilize Islamic education independently which gives influence to the religious mental citizens. In other words Kauman became a religious navigator of urban mental.

The class of trader in Kudus lives in a traditional dwelling house with a large courtyard and is bordered by a high walled fence with one accomplishment through the main gate. This concept as well as the embodiment to obtain privacy by providing protection to women. This pattern is a resemblance to the pattern of Muslim settlements in Arabian, as well as China. This situation is in contrast to Demak and Semarang, which are having many inhabitants of traders, but there are having an easier of lifestyle and independence. The form of dwelling house is simplier one. In Demak the traditional house also uses a tear roof, but simpler than in Kudus. While in Semarang is much simpler, small residential buildings with no courtyard, saddled with three-door facade detail. The artefacts found shows the influence of foreign culture in the expression of building architecture. Building houses in Demak, Kudus, Pati and Jepara showed similarity.

The shape of the roof of the pencu house is a representation of Javanese cosmology influenced by previous beliefs. Ornaments carved on the walls gebyok (wood carving) is the result of adaptation of Chinese culture. The opening of three doors on the front facade shows the influence of China. The placement of the bathroom at the front of the Kudus custom house shows the strong influence of Islam, whereby purification becomes an important part of a person before entering the house or to perform the prayer. In Kudus, the building of the house appears more expressive, representing the Gusjigang community of good Muslim morals and well-established economic traders (Sardjono 2015).

\subsection{The Form and Spatial Pattern reflects their Social Life}

The residence spatial In Demak-Kudus is structured at the mosque. There is a main road connecting it with the mosque, the road is wide enough (6 meters wide) so it can be passed by motor vehicle users. However residents prefer walking to the mosque. The mosque as the centre of orientation, and providing easy access for local residents to do worship in the mosque. This is one of application of the concept of Habluminallah (Sardjono, 2015). At Kauman Kudus was found a narrow road network pattern-enclosed by a wall of tall fencing the dwelling house. This is reminding us to the Muslim settlements in Arab countries, and also this pattern is found in Chinese merchant residential in Lasem area that built in the 18th century. There appears to be a symptom of mutual influence between Islam-ChineseJavanese and perhaps the Chinese merchants taking part in its spreading. The main streets of the area uses as an economic zone for the trading business manage by inhabitants. This zone is called semi public (Ekomadyo 1999), because the common people who can enter to this place is limited except who have ties to the institution inside.

Furthermore from the connecting road, there are a more limited access road leads to the inland of residence. This zone is called a private zone, because only residents can get into it. The road network pattern is similar of the main road network (shari), and the narrow road (fina) encountered in Muslim cities around the world (Tetuko 2000). Overall the pattern of the road network allow the whole area to be more controlled, especially the separation between public zones from economic activities and religious activities, for semi public from socialreligious activities and for private zones from residential activities. The above description is 
reminiscent of the place theories conveyed by Rapoport $(1977,2001)$, Cristian NordbergSchultz (1979), Lynch (1981), Trancyk (1986), Hayden (1986), and Tuan (2008), that physical formation of space these Muslim settlements are influenced by socio-cultural aspects that have taken root in the lives of their people. Morphological formation, the structure of the road, the division of zones in the Muslim settlement is a container of your community concept regarding habluminannas (Sardjono, 2015), which is the relationship between God's fellow creatures.

Religious activities centralized in the Grand Mosque, various ritual and social-religious activities are held periodically and eventually. Further is the connecting road that became intermediates into the housing section. In Semarang and Demak having the Plots systems from medium to small size, small to medium size of houses complete little size of yards. Different to Kauman Kudus and Jepara because of there are a wider land plots, the house is surrounded by a wide fence, because many of inhabitants are succeed trader. In Demak Kauman village spreads behind the mosque's mihrab to the west and ends of edge grave. In Demak the residence patterns are arranged regularly in the grid pattern. While in Semarang the residence pattern spreads more spontaneous of grid. This pattern called irregular pattern (Koztof 1991), or grid deformation though appears irregular but reflects the social life of the Muslim community in it (Hillier, Hanson and Peponis, 1987).

Kauman in Coastal shores area have different patterns one another. The feature of non-elite is seen in Demak-Semarang, with small plots and limited access, but in Kudus it is seen as an elite one. Regarding the structure, it is seen in Demak's concept of a clearer cosmological structure. Coastal shanties evolved at different speeds. In an ancient city like Kudus Kulon tends to be still conservative, surviving in originality (Suprapti, 2014). While in the big cities tend to be increasingly urged by the modern-capitalistic culture, so that affect the social life of society along with spatial settlements. Some important characteristic of the coastal Kauman are:

1. The division of public zones for economic and religious activities, semi-public zones for social-religious activities such as Islamic education and study groups, and private zones destined for housing activities.

2. The orientation of the building to the mosque, the pattern of the road network is limited.

3. Buildings with large and small lots. Except in Kudus even though many of Kauman's people succeed in their economic activities, but are modestly living in small houses.

4. Kauman is the driving force of religious social activities on a city scale. Ability to create the religious educational institutions needed by many townspeople.

5. Changes occur on coastal shores. Some of them have experienced the intrusion of functions caused by the rotation of the capitalist economy in the city centre.

From reviews of Muslim settlements in several coastal cities indicates an existence of a place that has brought together the physical character of the layout with its social cultural life (Rapoport 1977, Nordberg-Schultz 1979, Lynch 1981, Trancyk 1986, Hayden 1995, Tuan 2008). Place on the coastal Muslim settlements of Kauman has also radiated religious energy all over the city, driven by the scholars in conducting social activities. They not only perform rituals of worship in the mosque, run Islamic propagandas by way of religious science education through study groups, Islamic boarding schools, or regularly schools. They also engage in economic activity that concern to commercial-business which is inherited traditionally from Sufis. They also play in the political arena that puts forward 
Islamic missions. The Kauman community also performs ancestral cultural rituals (the majority of Javanese). Kauman Muslim residences in the day life activities produces the immaterial commodities in the form of mental spiritual, as well as the material in the form of goods for worship purposes, religious books, and related to Islamic worship.

\section{Conclusion}

North Coast of Java, especially the ancient cities of Demak, and Kudus, save the potential of Muslim cities reflecting the Islamic Shari'ah habluminallah \& habluminnas. The meaning of the spatial settlement of Muslims symbolizes the expression of the relationship between man and Almighty God (worship and carry out His command). and the relationship between humans and fellow beings (educate children, trade, do propaganda of Islam, social life).

Political, socio-cultural, economic, and spatial factors lie behind the establishment of a devout Muslim residence around the city's grand mosque known as Kauman.

The Kauman character that develops on the north coast of Java is a Muslim community settlement as follows:

a. Physically spread around and directly adjacent to the city's grand mosque, mosqueoriented residence, having a certain network pattern that tend to have a controlled access, and complete with various facility of socio-religious-economic.

b. The inhabitants are from the clergy, ustad, santri and ordinary citizens who are devoted to worship, from generation to generation residing in, endogamy marriage to maintain its authenticity, do an activity of daily life of Muslim (prayer, zakat, fasting, Hajj), and conduct religious propaganda through educational; perform certain ceremonies to express their existence.

c. The economic life is mainly supported by trading, independently lifestyle.

Morphologically both of the Kauman Demak and Kudus have a grid deformation pattern residence, especially in Kudus, the accessibility is very limited, as the purpose of controlling the area for women, children and for outsiders as well as business competitors.

Although they has the same location in coastal areas, but between the Kauman one another has a different character. More in-depth research is needed to explore those muslim residence characters in more detail.

\section{Acknowledgments}

Author would like to convey a gratitude to all whose have supported and motivated me to finish this paper. Especially to Prof. Nurdien H. Kistanto, the late Prof. Eko Budiharjo, the late Dr. Galih Widjil Pangarsa

\section{References}

Al Qurtuby, S. 2003, Arus Cina-Islam-Jawa, Jogyakarta : Inspeal Ahimsakarya Press.

Budihardjo, E. 2006. Sejumlah Masalah Permukiman Kota, Bandung : P.T. Alumni.

Budiarto, S., A. 2016. Concept of Self-Conservation in a Traditional Village; an Empirical Study of Kampung Kauman Semarang, Indonesia, International Transaction Journal of Engineering, Management, \& Applied Sciences \& Technologies 7 (1): 21-34

Darban, A., A. 2000. Sejarah Kauman: Menguak Identitas Kampung Muhammadiyah, ,Yogyakarta : Tarawang.

Ekomadyo, S., A. 1999. Thesis Kajian 'Kota Islam” Penelusuran Kaitan antara Ide-Ide Kota dalam Sumber Hukum Islam dengan Pola Tata Letak Fisik Perkotaan yang Ada, Bandung: Program Magister Arsitektur ITB. 
Geertz, C.1989. Abangan, Santri, Priyayi Dalam Masyarakat Jawa, Jakarta: Pustaka Jaya.

Hayden, D. 1995. The Power of Place, London; Thames Hudson Ltd.

Hillier, B.; Hanson, J. \& Peponis, J. 1987. Architecture \& Comportement Architecture \& Behaviour, Vol. 3 (1986-1987), Lausanne Switzerland

Koztof, S. 1991. The City Shaped, London: Thames Hudson Ltd.

Lombard, D. 2005 a. Nusa Jawa: Silang Budaya, Kajian Sejarah Terpadu, Bagian I: BatasBatas Pembaratan, Jakarta-Paris: PT Gramedia Pustaka Utama. 2005 b. Nusa Jawa: Silang Budaya, Kajian Sejarah Terpadu, Bagian II: Jaringan Asia, Jakarta-Paris : PT Gramedia Pustaka Utama. 2005 c. Nusa Jawa: Silang Budaya, Kajian Sejarah Terpadu, Bagian III: Warisan Kerajaan-Kerajaan Konsentris, Jakarta-Paris : PT Gramedia Pustaka Utama.

Lynch, K. 1981. Good City Form, USA: MIT Press

Marwoto. 2001. Tesis: Kampung Kauman di Pesisir Utara Jawa Tengah Kasus Studi: Kauman Jepara, Kauman Kudus Wetan dan Kauman Pati, Bandung: Program Magister Arsitektur, Institut

Pangarsa, W., G. 2006. Merah Putih Arsitektur Nusantara, Yogyakarta: Andi Offset.

Rapoport, A. 1977. Human Aspect of Urban Form, New York : Pargamon Press. 2005. Theory Social and Culture, Tylor and Francis Metapress Culture, Architecture and Design.

Sensa, M., S., D. 1981. Sebuah Pemikiran Tentang Permukiman Islam, Bandung : MITP UNISBA.

Serageldin, B. 2001. The Sacred City, New York : Routledge.

Suprapti, A. 1997. Kajian Pola Spasial Kampung Kauman Semarang Sebagai suatu 'Place', , Semarang : Tesis Magister Teknik Arsitektur UNDIP.

Suprapti, A.; Sardjono, B., A.; Harani, R., A.; Falah, N., Y. 2014. The Tradition of Living Muslim Community Kudus Kulon Indonesia, Journal of Social Sciences 10 (2); 63-73, Science Publications

http://doi:10.3844/jsssp.2014.63.73

Suprapti, A.; Kistanto, H., N.; Pandelaki, E., E.; Indrosaptono, D. 2018. Control of Spatial Protection in Kauman Semarang, Journal of Architecture and Urbanism 41 (4): 268277, Routledge Tylor and Francis group

https://doi.org/10.3846/20297955.2017.1402717

Tetuko, S. 2000. Tesis: Kajian Karakteristik Pola Permukiman Islam di Kauman Demak, Semarang : Program Pasca Sarjana Magister Teknik Arsitektur Universitas Diponegoro.

Thohir, M. 1997. Wacana Masyarakat Dan kebudayaan Jawa Pesisiran, Penerbit Bendera.

Tjandrasasmita, U. 2000. Pertumbuhan dan Perkembangan Kota-kota Muslim di Indonesia, Kudus: Penerbit Menara Kudus.

Trancik, R. 1986. Finding The Lost Space: Theories of Urban Design, New York : Van Norstrand Reinholld Company.

Triatmojo, S. 2010, Pemupakatan dan Desakralisasi Ruang Di Permukiman Kauman, Disertasi, Yogyakarta, Yogyakarta: Universitas Gajahmada Yogyakarta.

Tuan, Y., F. 2008, Space and Place : The Perspective of Experience, London : University of Minnesota Press.

Wiryotomo, P.,B.,A. 1995. Seni Bangunan dan Seni Binakota di Indonesia, Jakarta: PT Gramedia Pustaka Utama. 